\title{
Nomenclature for Healthcare Waste in the Healthcare Sector and Its Alignment with the Provisions Made by The World Health Organization's Manual for Healthcare Waste Management: A Scoping Review
}

\author{
Lydia Hangulu \\ Discipline of Psychology, Health Promotion Programme, University of KwaZulu-Natal, Durban 4041, \\ South Africa; lydiahangulu@yahoo.com
}

Received: 10 July 2018; Accepted: 5 November 2018; Published: 12 November 2018

\begin{abstract}
There is lack of uniform nomenclature for healthcare waste (HCW) globally, which could undermine efforts to develop and implement appropriate policies relating to healthcare waste management (HCWM) in developing countries. This study sought to understand the terminologies used to describe HCW, including their definitions, categories, classification, and how they align with those that are provided by the World Health Organization (WHO)'s global manual for HCWM from healthcare facilities. The study first identified terms from the existing literature; then, it conceptually mapped the literature, and identified gaps and areas of further inquiry. Six electronic databases-EBSCOhost, Open Access, ProQuest, PubMed, Web of Science, and Google Scholar were used to search for literature. A total of 112 studies were included in the study. Despite having various nomenclature for HCW globally that align with those provided by the WHO manual, the use of varying nomenclature could create confusion among healthcare workers in the quest of managing HCW properly, especially in low and middle-income countries (LMICs). Further studies must be conducted to determine how these terminologies are interpreted and implemented in practice by healthcare workers. This will help to understand how their implementation aligns with the recommendations provided by the WHO manual.
\end{abstract}

Keywords: healthcare waste; healthcare workers; health sector; scoping review; WHO

\section{Introduction}

Healthcare activities such as operative and diagnostic procedures that involve administering injections, medications, drips, and surgery improve the health and quality of life of individuals [1]. However, the healthcare waste (HCW) that is generated during these healthcare activities could have adverse effects on both the people and the environment if it is poorly managed [2,3]. The literature regarding healthcare waste management (HCWM) shows that large volumes of $\mathrm{HCW}$ is generated from healthcare facilities globally [4], and it is poorly managed, especially in low and middle-income countries (LMICs) [5]. The main factors attributed to poor HCWM practices in LMICs include: lack of financial investment and clear policies to manage HCW by most governments [3-6], low levels of knowledge by healthcare staff on how to handle HCW properly $[7,8]$, poor segregation practices among healthcare workers [9], and inappropriate transport for transporting HCW, which is driven by untrained drivers who are also not registered to handle HCW [10]. More so, there are inadequate technologies for treating HCW [11-14]; as a result, HCW is often illegally dumped, openly burnt, and buried in poorly managed dumpsites [10-17].

Poor management of HCW exposes healthcare workers, waste handlers, and the community members to toxins, injuries, and infections [2]. For example, in a study conducted in Tripoli, 
Libya, it was found that exposure to HCW among waste handlers caused $5 \%$ of them to develop hepatitis B virus, and $0.3 \%$ had hepatitis C virus [18]. Exposure to HCW can cause tuberculosis (TB) infections [19], and damage the respiratory, nervous, and reproductive systems of the patients, family members, caregivers, and the public. HCW has mutagenic, teratogenic, and carcinogenic effects [20]. Exposure to HCW can also cause diseases such as diarrhea, leptospirosis, typhoid, cholera, and HIV [21]. The disposal of HCW into unprotected dumpsites promotes scavenging for reusable items for reselling. For example, one study in India revealed that, in almost $10 \%$ of the healthcare facilities in the country, more than $30 \%$ of the three to six billion injections that were administered every year were done with used equipment [22]. Similarly, in 2009, 240 people in the state of Gujarat in India contracted hepatitis B, because medical care was delivered with previously used syringes that were acquired through the black market [23].

While the environmental and health impacts of HCW have been well documented, having an operationalised nomenclature 'terminology' for HCW is important. The World Health Organization (WHO), in its global manual for healthcare waste management, provides guidelines for all of the issues relating to the proper management of HCW from healthcare settings. The manual uses the nomenclature 'healthcare waste' to mean all of the waste that is generated as a result of healthcare activities, and further classifies HCW into non-hazardous and hazardous waste [2]. Despite having a global manual, different nomenclatures are used to describe HCW by various authors from high-income countries (HICs) and LMICs. For example, some have used 'medical waste' [10,12,18,19,21,23,24], 'biomedical waste' [1,3], 'hazardous waste' [20,25], 'hospital waste' [6,11,13], or 'yellow bag waste' [26,27]. Consequently, a study on HCWM practices in healthcare facilities in Botswana [16] found that the use of the nomenclature 'clinical waste' to mean HCW confused healthcare workers and the public. Both the healthcare workers and ordinary people correctly defined clinical waste as any waste from healthcare facilities, but failed to consider that HCW is further categorized as non-hazardous and hazardous waste. Failure to classify HCW into these categories resulted in the improper segregation of HCW [16]. In other contexts such as clinical practice, the consistence use of specific nomenclature in describing suicidal behavior is critical for case development among healthcare providers [28]. Furthermore, it is argued that consistent and specific nomenclature allows for appropriate diagnosis, treatment, and the subsequent creation of public policy [29]. Similarly, considering that HCWM practices involve cognitive behavior with a triadic relationship which involves peoples' perceptions, feelings, and actions, one can argue that using various nomenclatures to describe $\mathrm{HCW}$ could be confusing to waste generators and handlers, thereby affecting the HCWM practices. Despite having various nomenclatures to describe HCW, is not clear how they align with the definitions that are provided by the WHO's manual on HCWM. Furthermore, there is no scoping review that describes, defines, and characterizes HCW in comparison with the provisions made by the WHO manual.

This scoping review endeavors to determine the common nomenclatures for HCW from HICs and LMICs, including their definition, classification, and categorization in comparison to those provided by the WHO global manual for HCWM. This scoping review will answer three specific research questions: (1) What are the various nomenclatures that are used to describe HCW in HICs and LMICs? (2) To what extent do such nomenclatures align with the provisions made by the WHO manual on HCWM? (3) What are the gaps that exists in the literature? Findings of the review will add scientific knowledge to the body of literature on HCWM, and will help determine any inconsistencies that exist that will help make recommendations aimed at improving HCWM by healthcare workers and other policy implementers, especially in LMICs.

\section{Methods}

Unlike systematic reviews that aim at combining, summarizing, and synthesizing the findings of particular research [30], scoping reviews are conducted for the purpose of mapping the key concepts underpinning a research area, and the main sources and types of evidence that are available [31-33]. Scoping reviews can be undertaken as standalone projects in their own right, especially where an area 
is complex or has previously not been reviewed comprehensively [30]. This scoping review was conducted because to our knowledge, no such study has been conducted to explore and map the nomenclature that is used to describe, define, and categorize HCW in HICs and LMICs, in comparison with those provided in the WHO manual for HCW. Both deductive and inductive approaches were applied when conducting this review. First, search terms from the literature were identified. Secondly, the search terms that were identified in the literature were used to search for literature from various databases. Thirdly, the relevant literature was reviewed and selected, and finally, all of the selected literature was mapped.

\subsection{Identifying Search Terms}

We used an iterative process to conduct the searches. First, the WHO manual was read in order to derive the first term 'healthcare waste' for the search. The term healthcare waste was used to search and conduct a broad but rapid review of the literature. In order to identify the terms used by ordinary people, policy-makers, and stakeholders, news stories from the 20 newspapers retrieved from the South African print media database were searched. The search was limited to the South African print media, because it was the only available database for news stories within the university at the time of research. The characteristics of the newspapers are summarized in Supplementary Table S1. The various searches yielded the following terms: "healthcare waste", "medical waste", "clinical waste", "biomedical waste", and "hospital waste".

\subsection{Literature Search}

The initial search was conducted in September 2015 by two student assessors (LH and SM) under the supervision of (OA). Six electronic databases: EBSCOhost, Open Access, ProQuest, PubMed, Web of Science, and Google Scholar were used (see Supplementary Table S2 for the table of all of the databases that were used in the study). These databases were those available at the University of KwaZulu-Natal, Durban, South Africa. We chose both gray and peer-reviewed literature in order to have a broader coverage of the literature. From the initial search, the results were 9735 , and too broad. To limit the search, we developed an inclusion criteria to include: (1) only full texts of both grey and peer-reviewed literature that were available through the library at the University of KwaZulu-Natal, (2) literature published from 1990 to 2015, because this period had the highest hits, (3) only English literature, and (4) literature with key search terms in their title and/or their abstracts.

\subsection{Review and Selection of Literature}

After applying the inclusion criteria, 8468 studies were excluded, and 1267 remained. Thereafter, the two assessors (LH and SM) worked together to develop a set of explicit exclusion criteria. The exclusion criteria were applied independently by the two assessors, who met regularly to compare the assessments and resolve discrepancies. The criteria were applied as follows. Studies were removed if they: (1) were duplicates and (2) did not define, categorize, and classify HCW in their full texts. After applying the exclusion criteria, 107 duplicates were removed, and 1157 studies remained. A total of 1045 studies that did not define, categorize, or classify HCW in their full text were excluded. The remaining 112 studies (see supplementary table of all included studies Table S3) that met the criteria were mapped as summarized in the PRISMA flow chart in Figure 1. 


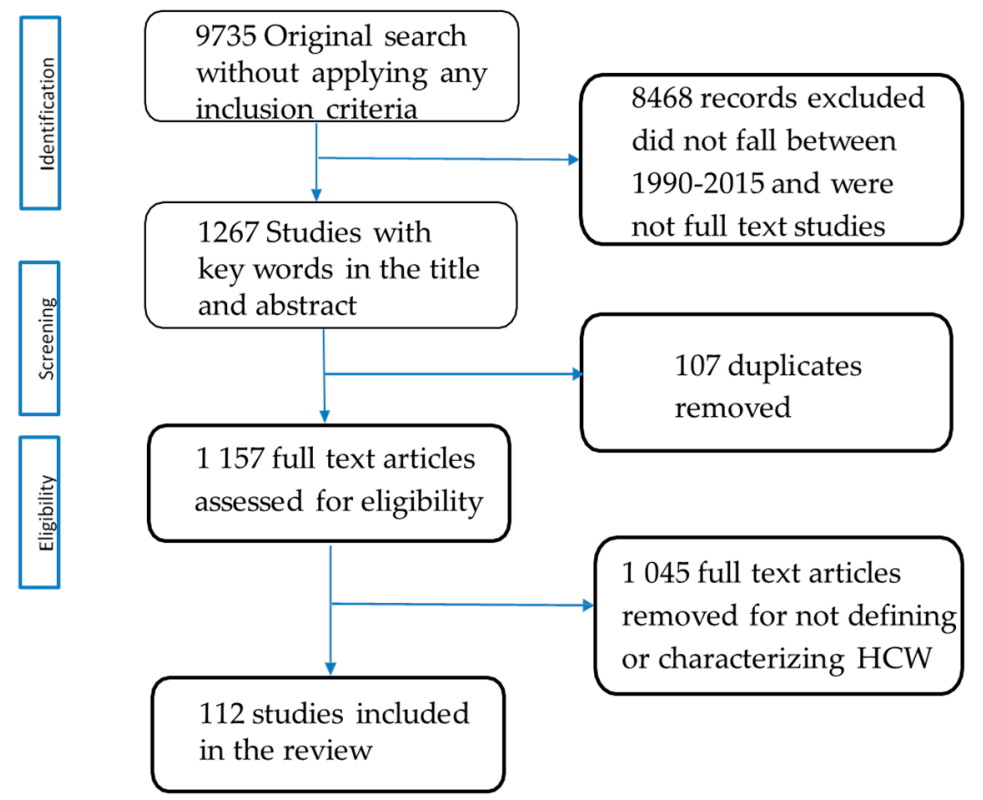

Figure 1. PRISMA flowchart of study selection process.

\section{Results}

The findings were coded using a coding framework which include the source of literature, country source, disciplines, topics covered, methods used and the common terminologies used all the details are discussed below (see the coding framework Supplementary Table S4).

\subsection{Characteristics of the Mapped Literature}

Source of literature: The majority of the studies $\mathrm{N}=100(89.3 \%)$, in this scoping review were published in journals, and $12(10.7 \%)$ were student dissertations. There were more studies $\mathrm{N}=100$ (89.28\%) from LMICs than from HICs $\mathrm{N}=12$ (10.71\%). The studies from LMICs are divided into regions. For example, the Asian countries included: Bangladesh, China, India, Lao Republic, Malaysia, Pakistan, Philippines, Romania, Thailand, Kingdom of Bahrain, Nepal, Vietnam, Taiwan. African countries include, Algeria, Botswana, Egypt, Ethiopia, Ghana, Libya, Nigeria, Tanzania, and Zimbabwe. The Middle East countries included: the kingdom of Buhrain, Iran, Jordan, and Palestine; further, there was Brazil from South America and Turkey from Europe (Turkey). The minority of the studies from HICs were from Croatia, Japan, the United Kingdom, Greece, Portugal, the United States of America, and Italy. All of these are summarized in Table 1. 
Table 1. A summary table for all low and middle-income countries (LMICs) and high-income countries (HICs) with various terminologies used.

\begin{tabular}{|c|c|c|c|c|c|}
\hline Region & Country & Terminology & Reference & $\begin{array}{l}\text { Number of } \\
\text { Studies } \\
(\mathrm{N}=112)\end{array}$ & Percentage \\
\hline \multirow{12}{*}{ Asia } & Bangladesh & $\begin{array}{l}\text { Hospital waste } \\
\text { Healthcare waste } \\
\text { Medical waste }\end{array}$ & $\begin{array}{c}\text { Akter et al., 1999, } \\
\text { Alam and Hossain 2013, } \\
\text { Rahman and Ali, 2000, } \\
\text { Patwary et al., } 2009\end{array}$ & 4 & 3.57 \\
\hline & China & $\begin{array}{l}\text { Biomedical waste } \\
\text { Clinical waste }\end{array}$ & $\begin{array}{c}\text { Chen et al., 2013, } \\
\text { Chung and Lo 2003, Tam, } 1996\end{array}$ & 3 & 2.67 \\
\hline & India & $\begin{array}{l}\text { Biomedical waste } \\
\text { Hazardous waste }\end{array}$ & $\begin{array}{c}\text { Chitnis et al., 2005, } \\
\text { Nema et al., 2011, } \\
\text { Ujwala, et al., 2012, } \\
\text { Naik et al., 2012, Babu et al., 2009, } \\
\text { Aravindan and Vasumathi, 2015, } \\
\text { Bansal et al., 2013, } \\
\text { Bhatt et al., 2013, } \\
\text { Imtiaz, et al., 2014, } \\
\text { Chaithra and Sadashivamurthy, 2014, } \\
\text { Chaurasia et al., 2014, } \\
\text { Chethana et al., 2014, } \\
\text { Chowdhary and Slathia, 2014, } \\
\text { Gupta et al., 2009, Sumi, 2010, } \\
\text { Singh et al., 2014, } \\
\text { Sehgal et al., 2015, } \\
\text { Sanjeev et al., 2014, } \\
\text { Rathod et al., 2012, } \\
\text { Rajor et al., 2012, } \\
\text { Prakash et al., 2015, Patil, 2015, } \\
\text { Nayak, and Nayak, 2014, } \\
\text { Kapoor et al., 2014, } \\
\text { Komilis et al., 2012 }\end{array}$ & 25 & 22.32 \\
\hline & $\begin{array}{l}\text { Lao } \\
\text { republic }\end{array}$ & Hospital waste & Saad, 2013 & 1 & 0.89 \\
\hline & Malaysia & Healthcare waste & $\begin{array}{l}\text { Shanmugasundaram, Soulalay and } \\
\text { Chettiyappan, } 2012\end{array}$ & 1 & 0.89 \\
\hline & Pakistan & Clinical waste & Ibrahim, 2005, Hossain et al., 2012 & 2 & 1.78 \\
\hline & Philippines & Biomedical waste & $\begin{array}{l}\text { Ali, H.A. 2000, Ibrahim, Z.B. 2005, } \\
\text { Hossain, et al., 2012, } \\
\text { Ambali et al., 2013, } \\
\text { Abdullah, et al., 2013, } \\
\text { Chitralekha and Agrawal, 2010, } \\
\text { Cruz et al., 2014. }\end{array}$ & 6 & 5.35 \\
\hline & Japan & Biomedical waste & Miyazaki and Une 2005 & 1 & 0.89 \\
\hline & Thailand & Healthcare waste & $\begin{array}{l}\text { Ananth et al., 2010, } \\
\text { Manowan, } 2009\end{array}$ & 2 & 1.78 \\
\hline & Nepal & $\begin{array}{c}\text { Hazardous } \\
\text { Healthcare waste }\end{array}$ & Sapkota et al., 2014 & 1 & 0.89 \\
\hline & Vietnam & Healthcare waste & Phengxay et al., 2005 & 1 & 0.89 \\
\hline & Taiwan & $\begin{array}{l}\text { Biomedical, } \\
\text { Medical waste }\end{array}$ & $\begin{array}{l}\text { Liao and Ho, 2014, } \\
\text { Cheng et al., } 2009\end{array}$ & 2 & 1.78 \\
\hline \multirow{4}{*}{ Africa } & Algeria & Healthcare waste & Bendjoudi et al., 2009 & 1 & 0.89 \\
\hline & Botswana & $\begin{array}{l}\text { Clinical waste } \\
\text { Biomedical waste } \\
\text { Healthcare waste }\end{array}$ & $\begin{array}{c}\text { Kang'ethe, 2008, Kudoma, 2013, } \\
\text { Mbongwe et al., 2008, } \\
\text { Mmereki et al., 2008, } \\
\text { Mmereki et al., 2017 }\end{array}$ & 5 & 4.46 \\
\hline & Cameroon & Clinical waste & $\begin{array}{l}\text { Mochungong, 2011, } \\
\text { Manga et al., } 2011\end{array}$ & 2 & 1.78 \\
\hline & Egypt & $\begin{array}{l}\text { Hospital waste } \\
\text { Biomedical waste }\end{array}$ & $\begin{array}{c}\text { El-Salam, 2010, } \\
\text { Soliman and Ahmed, } 2007\end{array}$ & 2 & 1.78 \\
\hline
\end{tabular}


Table 1. Cont.

\begin{tabular}{|c|c|c|c|c|c|}
\hline & Ethiopia & Healthcare waste & $\begin{array}{l}\text { Haylamicheal, et al., 2011, } \\
\text { Tesfahun et al. 2014, } \\
\text { Tadesse and Kumie, } 2014\end{array}$ & 3 & 2.67 \\
\hline & Ghana & Healthcare waste & Abor, 2013, Asante et al., 2014 & 2 & 1.78 \\
\hline & Libya & Healthcare waste & Sawalem et al., 2009 & 1 & 0.89 \\
\hline & Nigeria & $\begin{array}{l}\text { Biomedical waste } \\
\text { Hospital waste } \\
\text { Healthcare waste }\end{array}$ & $\begin{array}{l}\text { Turaki, 2015, Chima et al., 2014, } \\
\text { Joshua et al., 2014, Longe, 2012, } \\
\text { Ngwuluka et al., 2009, Abor, 2007, } \\
\text { Maseko, } 2014\end{array}$ & 7 & 6.25 \\
\hline & $\begin{array}{l}\text { South } \\
\text { Africa }\end{array}$ & $\begin{array}{l}\text { Medical waste } \\
\text { Healthcare waste }\end{array}$ & $\begin{array}{l}\text { Gabela and Knight, 2010, } \\
\text { Maseko, 2014, } \\
\text { Nemathaga et al., } 2008\end{array}$ & 3 & 2.67 \\
\hline & Tanzania & Hospital waste & Nemathaga et al., 2008 & 1 & 0.89 \\
\hline & Zimbabwe & Medical waste & $\begin{array}{c}\text { Mziray, 2009, } \\
\text { Taru and Kuvarega, } 2005\end{array}$ & 2 & 1.89 \\
\hline \multirow{4}{*}{$\begin{array}{l}\text { Middle } \\
\text { East }\end{array}$} & $\begin{array}{l}\text { Kingdom of } \\
\text { Bahrain }\end{array}$ & $\begin{array}{l}\text { Healthcare waste } \\
\text { Hospital waste }\end{array}$ & $\begin{array}{l}\text { Askarian et al., 2010, } \\
\text { Mesdaghinia, 2009, } \\
\text { Mohamed et al., } 2009\end{array}$ & 3 & 2.67 \\
\hline & Iran & $\begin{array}{l}\text { Healthcare waste } \\
\text { Medical waste } \\
\text { Hospital waste } \\
\text { Infectious waste }\end{array}$ & $\begin{array}{c}\text { Askarian et al., 2010, } \\
\text { Bazrafshan et al., 2014, } \\
\text { Taghipour and Mosaferi, 2009, } \\
\text { Sabour et al., 2007, } \\
\text { Oroei et al., 2014 }\end{array}$ & 5 & 4.46 \\
\hline & Jordan & Medical waste & $\begin{array}{l}\text { Abu-Awwad 2008, } \\
\text { Al-Khatib et al., 2011, } \\
\text { Qdais et al., } 2007\end{array}$ & 3 & 2.67 \\
\hline & Palestine & $\begin{array}{l}\text { Healthcare waste } \\
\text { Hospital waste }\end{array}$ & $\begin{array}{c}\text { Al-khatib et al., 2009, } \\
\text { Eleyan et al., 2013, } \\
\text { Maroufi, and Javadi, } 2012\end{array}$ & 3 & 2.67 \\
\hline \multirow{4}{*}{ American } & Brazil & $\begin{array}{l}\text { Hospital } \\
\text { Biomedical waste } \\
\text { Medical waste }\end{array}$ & $\begin{array}{l}\text { Ferreira et al., 2003, } \\
\text { Paiz et al., 2014, } \\
\text { Silva et al., } 2005\end{array}$ & 3 & 2.67 \\
\hline & $\begin{array}{c}\text { San } \\
\text { Salvador }\end{array}$ & Healthcare waste & Johnson et al., 2013 & 1 & 0.89 \\
\hline & Mexico & Medical waste & Spence, 2000 & 1 & 0.89 \\
\hline & $\begin{array}{l}\text { United } \\
\text { States of } \\
\text { America }\end{array}$ & Healthcare waste & Klangsin, 1994 & 1 & 0.89 \\
\hline \multirow{7}{*}{ European } & Turkey & $\begin{array}{l}\text { Medical waste } \\
\text { Hospital waste }\end{array}$ & $\begin{array}{l}\text { Akbolat and Saglam, 2011, } \\
\text { Eker et al., 2010, } \\
\text { Uysal and Tinmaz, 2004, } \\
\text { Altin et al., 2003 }\end{array}$ & 4 & 3.57 \\
\hline & Croatia & $\begin{array}{l}\text { Hazardous medical } \\
\text { waste }\end{array}$ & Marinković et al., 2008 & 1 & 0.89 \\
\hline & $\begin{array}{l}\text { United } \\
\text { Kingdom }\end{array}$ & $\begin{array}{l}\text { Hazardous waste } \\
\text { Healthcare waste } \\
\text { Clinical waste } \\
\text { Medical waste }\end{array}$ & $\begin{array}{c}\text { Blenkharn, 2006, } \\
\text { Akpieyi et al., 2015, Moritz, 1995, } \\
\text { Pudussery, } 2010\end{array}$ & 4 & 3.57 \\
\hline & Greece & $\begin{array}{l}\text { Hospital waste } \\
\text { Medical waste }\end{array}$ & $\begin{array}{l}\text { Tsakona et al., 2007, } \\
\text { Graikos et al., } 2010\end{array}$ & 2 & 1.89 \\
\hline & Portugal & Medical waste & Botelho, 2012 & 1 & 0.89 \\
\hline & Italy & Medical waste & Giacchetta and Marchetti, 2013 & 1 & 0.89 \\
\hline & Romania & Medical waste & Bulucea et al., 2008 & 1 & 0.89 \\
\hline
\end{tabular}




\subsection{Disciplines Represented by the Various Studies}

The 112 studies were from science-related disciplines ranging from administrative science and policy to process engineering. The studies covered various topics for example, $44(39.3 \%)$ covered HCWM practices, 14 (12.5\%) discussed the knowledge and attitudes of healthcare staff about HCWM, $13(11.6 \%)$ addressed the segregation and quantification of HCW, $12(10.7 \%)$ presented the risks associated with HCWM, 11 (9.8\%) focused on HCW treatment and disposal options, nine (8.0\%) reviewed existing policies on HCWM, and nine ( $8.0 \%)$ addressed models for HCWM. The majority $22(19.6 \%)$ of the studies were cross-sectional studies followed by 16 mixed methods $(14.3 \%)$, 13 literature reviews (11.6\%), 13 quantitative surveys (11.6\%), 11 case studies $(9.8 \%)$, eight qualitative studies $(7.1 \%)$, six experiments $(5.4 \%)$, five document analyses $(4.5 \%)$, two commentaries $(1.8 \%)$ and three systematic reviews $(2.8 \%)$.

\subsection{The Common Terminologies Used to Describe Healthcare Waste by Various Countries}

The WHO manual uses the term 'healthcare waste' to describe all of the waste resulting from healthcare activities. The common terminologies used by HICs are medical waste (4.46\%), healthcare waste, and hospital waste (1.78\% each), followed by clinical, biomedical, and hazardous waste, at $0.89 \%$ each. In the LMICs, biomedical waste was found to be the common terminology used with $32.14 \%$, followed by healthcare waste $(24.10 \%)$, medical waste $(13.39 \%)$, hospital waste $(10.71 \%)$, clinical waste $(6.25 \%)$, and hazardous healthcare waste $(2.67 \%)$, as summarized in Table 2.

Table 2. The common terminologies used by LMICs and HICs to describe healthcare waste.

\begin{tabular}{cccc}
\hline Country Focus & Common Terminology & Number of Studies & Total Percentage \\
\hline & Medical Waste & 5 & 4.46 \\
& Healthcare Waste & 2 & 1.78 \\
& Hospital Waste & 2 & 1.78 \\
High-Income Countries & Clinical Waste & 1 & 0.89 \\
& Biomedical Waste & 1 & 0.89 \\
& Hazardous Waste & 1 & 0.89 \\
& & & $(89.28)$ \\
\hline \multirow{4}{*}{ Low and Middle-Income } & Biomedical Waste & 36 & 32.14 \\
Countries & Healthcare Waste & 27 & 24.10 \\
& Medical Waste & 15 & 13.39 \\
& Hospital Waste & 12 & 10.71 \\
& Clinical Waste & 7 & 6.25 \\
& Hazardous Healthcare & 3 & 2.67 \\
\hline
\end{tabular}

\subsection{Categorization of Healthcare Waste}

The WHO manual categorizes HCW into non-hazardous and hazardous waste. All of the categories presented by the eligible studies from LMICs conformed to the WHO's categories despite using terminologies such as biohazardous or pathological waste to mean all of the waste that is capable of transmitting microbes, and non-biohazardous/non-pathological waste as waste that does not pose harm upon contact, as presented in Table 3.

On the other hand, the HICs categorizes all waste into five groups/classes using letters of the alphabet. These groups are Group A waste, which is all waste with human tissue including blood, animal carcasses, tissue from veterinary centers, hospitals, and laboratories. Group B waste consists of all discarded syringes needles, cartridges, broken glass, and any other contaminated disposable sharp instruments. Group C waste includes all microbiological cultures and all potentially infected waste from pathology departments such as clinical or research laboratories and post-mortem rooms. Group D waste are all of the pharmaceutical products and chemical wastes. Group E waste includes all 
of the items that are used to dispose of urine, feces, body secretions, and excretions, as summarized in Table 4. Despite using letters of the alphabet to categorize HCW, the description of the HCW as well as the examples that are provided under each category align with those provided by the WHO manual.

Table 3. Classification of healthcare waste by low and middle-income countries.

\begin{tabular}{ll}
\hline \multicolumn{1}{c}{ Classification of Healthcare Waste } & \multicolumn{1}{c}{ Examples of Waste } \\
\hline 1. Biohazardous/Pathological Waste & $\begin{array}{l}\text { Waste suspected to contain pathogens } \\
\text { e.g., laboratory cultures; waste from isolation wards; } \\
\text { tissues (swabs), materials, or equipment that have been } \\
\text { in contact with infected patients; excreta }\end{array}$ \\
\hline Infectious waste & $\begin{array}{l}\text { Human tissues or fluids } \\
\text { e.g., body parts; blood and other body fluids; fetuses }\end{array}$ \\
\hline Pathological waste & $\begin{array}{l}\text { This is sharp waste } \\
\text { e.g., needles; infusion sets; scalpels; knives; blades; } \\
\text { broken glass }\end{array}$ \\
\hline Pharmaceutical waste & $\begin{array}{l}\text { Waste containing pharmaceuticals } \\
\text { e.g., pharmaceuticals that are expired or no longer } \\
\text { needed; items contaminated by or containing } \\
\text { pharmaceuticals (bottles, boxes) }\end{array}$ \\
\hline Genotoxic waste & $\begin{array}{l}\text { Waste containing substances with genotoxic properties } \\
\text { e.g., waste containing cytostatic drugs (often used in } \\
\text { cancer therapy); genotoxic chemicals }\end{array}$ \\
\hline Chemical waste & $\begin{array}{l}\text { Waste containing chemical substances } \\
\text { e.g., laboratory reagents; film developer; disinfectants } \\
\text { that are expired or no longer needed; solvents }\end{array}$ \\
\hline $\begin{array}{l}\text { Waste containing radioactive substances } \\
\text { e.g., unused liquids from radiotherapy or laboratory } \\
\text { research; contaminated glassware, packages, or } \\
\text { absorbent paper; urine and excreta from patients treated } \\
\text { or tested with unsealed radionuclides; sealed sources }\end{array}$ \\
\hline \begin{tabular}{l} 
Paper, plastic, cans, leftover food \\
\hline
\end{tabular}
\end{tabular}

Table 4. Classification of healthcare waste by high-income countries.

\begin{tabular}{cl}
\hline Classification of Healthcare Waste & \multicolumn{1}{c}{ Examples } \\
\hline Group A & $\begin{array}{l}\text { All waste contaminated with human tissue, including } \\
\text { blood, animal carcasses, tissue from veterinary } \\
\text { centers, hospitals, and laboratories, including soiled } \\
\text { surgical dressing, swabs, and other soiled waste from } \\
\text { treatment areas }\end{array}$ \\
\hline Group B & $\begin{array}{l}\text { All discarded syringe needles, cartridges, broken } \\
\text { glass, and any disposable sharp instruments }\end{array}$ \\
\hline Group C & $\begin{array}{l}\text { All microbiological cultures and all waste from } \\
\text { pathology departments such as clinical or research } \\
\text { laboratories and post-mortem rooms }\end{array}$ \\
\hline Group D & $\begin{array}{l}\text { All pharmaceutical products and chemical wastes } \\
\text { e.g., all discarded medicines, cytotoxic drugs }\end{array}$ \\
\hline Group E & $\begin{array}{l}\text { All items that are used to dispose of urine, feces, body } \\
\text { secretions, and excretions e.g., incontinence pads, } \\
\text { disposable bedpans, urine containers }\end{array}$ \\
\hline
\end{tabular}




\section{Discussion}

The majority of the studies were from LMICs, which shows that HCWM is more of a concern in LMICs [2-26,30]. In order to address the issue of HCWM, the 112 studies in this review used various methods ranging from case studies to systematic reviews. The studies are spread across different disciplines, with the largest number coming from the public health discipline, followed by environmental engineering, environmental health, environmental management, waste management engineering, and lastly, community medicine. These findings show that HCW is a multidisciplinary issue $[22,31]$ that has implications for the well-being of the people and the environment.

This review has also found that both HICs and LMICs use different terminologies to describe $\mathrm{HCW}$, although the definition, categorization, and classification align with those provided by the WHO manual [2]. It is not clear why the use of nomenclature vary in countries, and yet, there is only one global manual. More so, the adverse consequences of the improper management of HCW have been documented extensively [2,18-23], and using different nomenclatures to describe HCW is one of the factors contributing to the improper segregation practices of HCW among healthcare workers [4]. For example, a study in Botswana on HCWM current practices in healthcare facilities [16] found that the term 'clinical waste' is known to mean all of the waste that is generated from healthcare facilities. Due to this definition, most healthcare workers and the general public ended up not segregating HCW into non-hazardous and hazardous waste. The health workers disposed of all of the unsegregated $\mathrm{HCW}$ into red bags. The consequence of this practice was the unnecessary use and wasting of red bags, and the overloading of resources needed for the transportation and storage of HCW. Although this particular study cannot be generalized, more of such studies are yet to be found. Varied nomenclatures could also cause confusion when it comes to developing HCWM policies by policy-makers, and can affect the practices of HCWM by healthcare workers who are generators and handlers of HCW. More importantly, a lesson learnt from Mbongwe's study is the need to have a standard nomenclature to describe, define, categorize, and classify HCW.

\section{Conclusion and Recommendations}

Considering that all of the nomenclatures that are used by various authors from HICs and LMICs are different, but align with those provided by the WHO manual, there is a need to adopt the terminology used by the manual. A uniform nomenclature could be beneficial for the healthcare workers who are HCW generators and handlers. A standard nomenclature could also be beneficial to policy-makers for designing HCWM policies that monitor appropriate HCWM practices.

\section{Strengths and Limitations}

The primary strength of this scoping review is its ability to answer all of the research questions with the use of transparent methods to conduct the review. Limitations to this scoping review are that only six databases were used to search for literature given the limited resources (at the University of KwaZulu-Natal). Furthermore, only 20 South African print media were used to identify search terms, because these were the only ones available at the time of the research. The search only used five key search terms (HCW, medical waste, clinical waste, biomedical waste, and hospital waste), because these are the most dominant terminologies found in the literature. Lastly, the review did not cover literature from 2016 onwards due to limited resources at the time of research.

\section{Areas for Future Research}

This scoping review did not explore the extent to which the WHO's guidelines have been adopted and implemented in practice by various countries. Such studies should be conducted to provide more insights into HCW and its management. More importantly, this review did not include literature from 2016 onwards. More studies should be conducted and include literature from 2016 onwards. This review did not explore search terms that are used in other media venues besides the ones from 
the South African print media. Other studies should be conducted to include search terms from other media venues to help yield more insights into the study on HCWM.

Supplementary Materials: The following are available online at http:/ www.mdpi.com/2313-4321/3/4/51/s1, Table S1: Characteristics of newspaper covered in the analysis; Table S2: Table showing databases used in the study; Table S3: A list of all references analysed for the scoping review. Table S4: Coding framework used for the studies included in the scoping review.

Funding: This research received no external funding.

Acknowledgments: Lydia Hangulu (L.H.) would like to acknowledge the assistance provided by the Samantha Moodley (S.M.) for working as an assessor in the data collection phase. More importantly, Olagoke Akintola (O.A.) who supervised the research. The writing of the manuscript was supported by the postdoctoral fellowship grant offered to Lydia Hangulu by the National Research Foundation (NRF) of South Africa. However, all views expressed in this manuscript are of the author and should and not necessarily to be attributed to NRF.

Conflicts of Interest: The author declares no conflict of interest.

\section{References}

1. Verma, L.K.; Mani, S.; Sinha, N.; Rana, S. Biomedical waste management in nursing homes and smaller hospitals in Delhi. Waste Manag. 2008, 28, 2723-2734. [CrossRef] [PubMed]

2. Chartier, Y.; Emmanuel, J.; Pieper, U.; Prüss, A.; Rushbrook, P.; Stringer, R.; Townend, W.; Wilburn, S.; Zghondi, R. Safe Management of Wastes from Health-Care Activities, 2nd ed.; World Health Organization: Geneva, Switzerland, 2014.

3. Mathur, P.; Patan, S.; Shobhawat, A.S. Need of biomedical waste management system in hospitals-An emerging issue-a review. Curr. World Environ. 2017, 7, 117-124. [CrossRef]

4. Ali, M.; Wang, W.; Chaudhry, N.; Geng, Y. Hospital waste management in developing countries: A mini review. Waste Manag. Res. 2017, 35, 581-592. [CrossRef] [PubMed]

5. Delmonico, D.V.; Santos, H.H.; Pinheiro, M.A.; de Castro, R.; de Souza, R.M. Waste management barriers in developing country hospitals: Case study and AHP analysis. Waste Manag. Res. 2018, 36, 48-58. [CrossRef] [PubMed]

6. Sawalem, M.; Selic, E.; Herbell, J.D. Hospital waste management in Libya: A. case study. Waste Manag. 2009, 29, 1370-1375. [CrossRef] [PubMed]

7. Kumar, R.; Khan, E.A.; Ahmed, J.; Khan, Z.; Magan, M.; Mughal, M.I. Healthcare waste management in Pakistan: Current situation and training options. J. Ayub Med. Coll. Abbottabad 2010, 22, 101-105. [PubMed]

8. Mmereki, D.; Baldwin, A.; Li, B.; Liu, M. Healthcare waste management in Botswana: Storage, collection, treatment and disposal system. J. Mater. Cycles Waste Manag. 2017, 19, 351-365. [CrossRef]

9. Ferreira, V.; Teixeira, M.R. Healthcare waste management practices and risk perceptions: Findings from hospitals in the Algarve region, Portugal. Waste Manag. 2010, 30, 2657-2663. [CrossRef] [PubMed]

10. Komilis, D.P. Issues on medical waste management research. Waste Manag. 2016, 48, 1-2. [CrossRef] [PubMed]

11. Nemathaga, F.; Maringa, S.; Chimuka, L. Hospital solid waste management practices in Limpopo Province, South Africa: A case study of two hospitals. Waste Manag. 2008, 28, 1236-1245. [CrossRef] [PubMed]

12. Hassan, M.M.; Ahmed, S.A.; Rahman, K.A.; Biswas, T.K. Pattern of medical waste management: Existing scenario in Dhaka City, Bangladesh. BMC Public Health 2008, 8, 36. [CrossRef] [PubMed]

13. El-Salam, M.M.A. Hospital waste management in El-Beheira Governorate, Egypt. J. Environ. Manag. 2010, 91, 618-629. [CrossRef] [PubMed]

14. Gabela, S.D.; Knight, S.E. Healthcare waste management in clinics in a rural health district in KwaZulu-Natal: Brief report. S. Afr. J. Epidemiol. Infect. 2010, 25, 19-21. [CrossRef]

15. Hangulu, L.; Akintola, O. Health care waste management in community-based care: Experiences of community health workers in low resource communities in South Africa. BMC Public Health 2017, 17, 448. [CrossRef] [PubMed]

16. Mbongwe, B.; Mmereki, B.T.; Magashula, A. Healthcare waste management: Current practices in selected healthcare facilities, Botswana. Waste Manag. 2008, 28, 226-233. [CrossRef] [PubMed]

17. Manga, V.E.; Forton, O.T.; Mofor, L.A.; Woodard, R. Health care waste management in Cameroon: A case study from the Southwestern Region. Resour. Conserv. Recycl. 2011, 57, 108-116. [CrossRef] 
18. Franka, E.; El-Zoka, A.H.; Hussein, A.H.; Elbakosh, M.M.; Arafa, A.K.; Ghenghesh, K.S. Hepatitis B virus and hepatitis C virus in medical waste handlers in Tripoli, Libya. J. Hosp. Infect. 2009, 72, 258-261. [CrossRef] [PubMed]

19. Bdour, A.; Altrabsheh, B.; Hadadin, N.; Al-Shareif, M. Assessment of medical wastes management practice: A case study of the Northern part of Jordan. Waste Manag. 2007, 27, 746-759. [CrossRef] [PubMed]

20. Blackman, W.L., Jr. Basic Hazardous Management; Lewis: Boca Raton, FL, USA, 1993.

21. Mato, R.R.A.; Kassenga, G.R.; Mbuligwe, S.E. Tanzania Environmental Profile; Report prepared for Japan International Co-operation (JICA): Dar es Salaam, Tanzania, 1997.

22. Harhay, M.O.; Halpern, S.D.; Harhay, J.S.; Olliaro, P.L. Health care waste management: A neglected and growing public health problem worldwide. Trop. Med. Int. Heal. 2009, 14, 1414-1417. [CrossRef] [PubMed]

23. Solberg, K.E. Trade in medical waste causes deaths in India. Lancet 2009, 373, 1067. [CrossRef]

24. Abdulla, F.; Qdais, H.A.; Rabi, A. Site investigation on medical waste management practices in northern Jordan. Waste Manag. 2008, 28, 450-458. [CrossRef] [PubMed]

25. LaGrega, M.D.; Buckingham, P.L.; Evans, J.C. Hazardous Waste Management; Waveland Press: Long Grove, IL, USA, 2010.

26. Diaz, L.F.; Eggerth, L.L.; Enkhtsetseg, S.; Savage, G.M. Characteristics of healthcare wastes. Waste Manag. 2008, 28, 1219-1226. [CrossRef] [PubMed]

27. Ramokate, T. Knowledge and Practices of Doctors and Nurses about Management of Health Care Waste at Johannesburg Hospital in the Gauteng Province, South Africa. Doctoral Dissertation, University of Witwatersrand, Johannesburg, South Africa, 2008.

28. Bryan, C.J. (Ed.) Cognitive Behavioral Therapy for Preventing Suicide Attempts: A Guide to Brief Treatments Across Clinical Settings; Routledge: London, UK, 2015.

29. De Leo, D.; Burgis, S.; Bertolote, J.M.; Kerkhof, A.J.; Bille-Brahe, U. Definitions of suicidal behavior: Lessons learned from the WHO/EURO Multicentre Study. Crisis 2006, 27, 4-15. [CrossRef] [PubMed]

30. Chircop, A.; Bassett, R.; Taylor, E. Evidence on how to practice intersectoral collaboration for health equity: A scoping review. Crit. Public Heal. 2015, 25, 178-191. [CrossRef]

31. Mays, N.; Roberts, E.; Popay, J. Synthesising Research Evidence: Studying the Organisation and Delivery of Health Services: Research Methods; Routledge: London, UK, 2001; pp. 188-220.

32. Arksey, H.; O’Malley, L. Scoping studies: Towards a methodological framework. Int. J. Soc. Res. Methodol. 2005, 8, 19-32. [CrossRef]

33. Daudt, H.M.; Van Mossel, C.; Scott, S.J. Enhancing the scoping study methodology: A large, inter-professional team's experience with Arksey and O'Malley's framework. Med. Res. Methodol. 2013, 13, 48. [CrossRef] [PubMed]

(C) 2018 by the author. Licensee MDPI, Basel, Switzerland. This article is an open access article distributed under the terms and conditions of the Creative Commons Attribution (CC BY) license (http://creativecommons.org/licenses/by/4.0/). 